DOI: $10.17516 / 1997-1370-0770$

УДК 008: $304.2+379.81$

\title{
Specifics of Cultural Space \\ of the Khabarovsk Territory
}

\author{
Lidiya V. Sheremet'eva* \\ Khabarovsk State Institute of Culture \\ Khabarovsk, Russian Federation
}

Received 26.03.2021, received in revised form 16.04.2021, accepted 21.05.2021

\begin{abstract}
The paper focuses on various activities of cultural institutions operating in the territory of the region. The methodological basis of the research is L.V. Nikiforova's cultural expertise based on systematisation of the categories of «places» of cultural space. The paper is a preparatory stage of cultural expertise, which aims to thoroughly analyse the network of cultural institutions in general and to identify potential art-spaces for further detailed study. It provides a detailed analysis of the network of cultural institutions in Khabarovsk and an overview of the categories of cultural institutions in the administrative centers of all districts in the Khabarovsk territory. The source base of the study is the data obtained from the analysis of websites of cultural institutions, social networks, as well as the respondents' personal surveys. Cultural institutions representing different forms of cultural activity have been roughly divided into ten groups. The result of the research is a perspective to identify institutions the activities of which can be evaluated in terms of belonging to the art-space format.
\end{abstract}

Keywords: culture, society, region, cultural space, art-space, Khabarovsk, Khabarovsk Territory, research activities, cultural expertise, cultural institutions.

Research area: 24.00 .00 - culturology.

Citation: Sheremet'eva, L.V. (2021). Specifics of the cultural space of the Khabarovsk Territory. J. Sib. Fed. Univ. Humanit. Soc. Sci., 14(6), 918-926. DOI: 10.17516/1997-1370-0770.

(C) Siberian Federal University. All rights reserved

* Corresponding author E-mail address: sheremetevalidiya@mail.ru ORCID: 0000-0002-0196-8262 


\title{
Специфика культурного пространства Хабаровского края
}

\author{
Л.В.Шереметьева \\ Хабаровский государственный институт культуры \\ Российская Федераџия, Хабаровск
}

\begin{abstract}
Аннотация. В работе проанализирована культурная среда региона, понимаемая как часть инфраструктуры культуры в ее региональном измерении. Исследованы различные направления деятельности учреждений культуры, функционирующих на территории края. В качестве методологической модели для проведения культурологической экспертизы использована предложенная Л.В. Никифоровой систематизация категорий «мест» культурного пространства. Целью статьи является выполнение подготовительного этапа культурологической экспертизы, цель которого, в свою очередь, анализ сети учреждений культуры в целом и выявление потенциальных арт-пространств для дальнейшего их детального изучения. Представлен подробный анализ сети учреждений культуры Хабаровска, а также обзор категорий учреждений культуры административных центров всех районов Хабаровского края (города: Хабаровск, Комсомольск-на-Амуре, Амурск, Советская Гавань, Николаевск-на-Амуре, Вяземский, Бикин; поселки: Ванино, Охотск, Переяславка, Солнечный, Чегдомын; села: Аян, Троицкое, Богородское, имени Полины Осипенко, Чумикан). Источниковой базой исследования выступали данные, полученные в результате анализа сайтов учреждений культуры, социальных сетей, а также личных опросов респондентов. Учреждения культуры, представляющие разные формы культурной деятельности, были условно разделены на десять групп: музейные организации; галереи / выставочные пространства; зоопарки; театры / театральные студии; библиотеки / книжные клубы; парки; концертные площадки; художественные студии; кинотеатры / киноклубы; образовательные площадки. Сделан вывод о различной степени разнообразия видов деятельности учреждений культуры в различных населенных пунктах. Также выявлены наиболее и наименее распространенные категории. Проведенное исследование позволяет определить учреждения, чья деятельность может быть оценена с точки зрения принадлежности к формату арт-пространства.
\end{abstract}

Ключевые слова: культура, социум, регион, культурное пространство, артпространство, Хабаровск, Хабаровский край, исследовательская деятельность, культурологическая экспертиза, учреждения культуры.

Научная специальность: 24.00.00 - культурология.

\section{Introduction}

The cultural space of a region can be defined as part of the infrastructure of culture in its regional dimension, local concentration. Everything created by man through the creative transformation of the environment in a particular region will enter the cultural space and form a zone of special cultural experience. Modern cultural space is characterized as mo- bile, multidirectional, constantly transforming, and contributing to the emergence of new ways to realize the residents' creative potential.

As a manifestation of a person's free selfexpression, art space is a form of cultural space organization; a publicly accessible space created and supported by the representatives of the creative class to provide an opportunity to realize an individual's creative potential, his/ 
her active participation in the cultural space formation.

It should be noted that in relation to this new phenomenon of culture the conceptual framework is still poorly developed. The theoretical and methodological base is not fully formed either. This does not allow for a detailed study of art spaces as well as of cultural and social processes taking place in them and, thus, justifies the need to develop a suitable methodology and a more thorough study.

\section{Theoretical framework}

The actual method of research that can be applied to the study of art space is cultural expertise belonging to the category of new types of expertise which arose in the course of updating the expert activity at the present stage of the society development. Compared to traditional types of expertise, new types of expertise that emerged in the late $20^{\text {th }}$-early $21^{\text {st }}$ centuries have their specific characteristics.

Cultural expertise is in the process of forming and determining its place among other types of expert activity. It is becoming more and more popular in socio-cultural practice and, as a result, more and more widespread. The need for it is due to the growing role of culture in social practice, the complication of social and cultural processes themselves, and the increase in its uncertainty and ambiguity.

\section{Methods}

Within the framework of this study, we follow A.P. Sadokhin and L.V. Nikiforova's works and regard cultural expertise as «a special type of research activity, the methodological basis of which is a cultural approach that aims to establish the cultural significance and value of objects, facts, phenomena and judgments of the cultural sphere» (Sadokhin, 2012). Cultural expertise is aimed at identifying general and particular features of the object of expertise and conducting its comparative typology, which leads to the establishment of its individual specifics based on a set of particular features.

The systematization of categories of «places» of cultural space proposed by L. V. Nikiforova (Nikiforova et al., 2011) is used as a model for cultural expertise. As part of this work, it is supplemented by a preparatory stage including a preliminary analysis of the cultural space as a whole. The study of the entire network of cultural institutions in the region will reveal the specifics of the cultural space, its content, and the form of activities carried out. A detailed analysis of the cultural space of the region allows us to identify potential art spaces in it, which will be further investigated using the method of cultural expertise.

\section{Statement of the problem}

The purpose of this study is to perform the preparatory stage of cultural expertise of the cultural space of the Khabarovsk Territory. In this article, both the cultural space of Khabarovsk as well as the data obtained from the study of sites of cultural institutions, social networks and the respondents' personal surveys, characterizing the diversity of the cultural sphere of other administrative centers of the region will be considered in more detail. In total, the activities of 227 regional institutions working in 10 areas were analyzed. It is noteworthy that many of the organizations carry out their activities simultaneously in several directions. This allows to assign the same institution to several categories at once and increases the number of names in them. Thus, the sum of the names of all groups may exceed the actual number of institutions in the locality.

\section{Discussion}

Khabarovsk Territory is a subject of the Russian Federation located in the Far East. The administrative center is Khabarovsk. The area of the region occupies $787633 \mathrm{~km}^{2}$; the population is 1315 643. The administrative-territorial region is divided into 17 municipal districts. In the course of the study, the cultural institutions of the administrative centers of all districts were analyzed.

Khabarovsk is one of the largest cultural, educational and political centers of the Russian Far East with a population of 616372. In the course of the study of the urban cultural space, the existing network of cultural organizations in the city (both public and private) carrying out work on various types of activities was an- 
alyzed. In total, we studied 91 institutions representing different forms of cultural activity. They were divided into 10 groups: 1) museum organizations; 2) galleries / exhibition spaces; 3) zoos; 4) theaters / theater studios; 5) libraries / book clubs; 6) parks; 7) concert venues; 8) art studios; 9) cinemas / film clubs; 10) educational venues. The analysis of the quantitative values of each of these groups clearly shows the ratio of the activity of sites in different spheres.

The group of museum organizations in Khabarovsk is one of the most numerous. It is represented by 14 names ( $15 \%$ of the total number of organizations). It is important to point out that this group includes both public and private institutions (for example, «The world of talking machines» museum), including those that are not included in the All-Russian Register of Museums, but carry out activities that can be described as museum-educational (the Museum of Living History, located in the Center for military-patriotic education «Vzlet»).

The group of institutions, which includes cinemas and film clubs, has 14 organizations (15\% of the total number). This category includes 9 cinemas and 5 film clubs/film lecture halls for film discussions by viewing participants. Film lectures and film clubs can be located in educational institutions (film lectures in the Khabarovsk Theological Seminary), museums («Silent Friday» in the museum named after N.I. Grodekov), or autonomous art venues (film screenings in the art space «Platonnika»).

The category of concert venues, which has 14 names (16\% of the total number), includes both state organizations (the City Palace of Culture, the Philharmonic Concert Hall) and private ones (the bar «Harat's pub»). They provide opportunities for the performances by both local and visiting musicians.

The network of libraries and book clubs that recently appeared in Khabarovsk includes 10 organizations (10\% of the total number), libraries and their branches being predominant. They often try to combine several types of activities and also hold musical evenings, festive programs with master classes, lectures.

There are 10 theaters and theater studios in the city (11\% of the total number).
The number of parks that perform a recreational and educational function (for example, an Arboretum) and get involved acting in organizing the citywide festive events in Khabarovsk is 8 . They make $9 \%$ of the total number of cultural institutions.

There are 6 art studios in the city $(7 \%$ of the total number). They do not only conduct regular classes, but also offer lectures and master classes in various types of decorative and applied arts. It should be noted that the studios are targeted at a multi-age audience and provide classes for mixed groups as well.

Most of the galleries and exhibition spaces ( 5 organizations $-6 \%$ of the total) are represented by private institutions: SKV gallery, «Rizoma» gallery, «List» gallery-salon. These organizations, unlike state-owned ones (Art gallery named after A. M. Fedotov, the regional scientific and educational association of culture), combine several types of services and can also offer rental of premises, work as event agencies or baguette workshops.

In the city and suburbs, there are 4 stationary and mobile zoos ( $4 \%$ of the total number): Priamursky zoo named after V.P. Sysoev, «Amur Fish» museum-aquarium, and two tactile zoos.

$7 \%$ of the total number is constituted by 6 educational venues implemented at various venues: lecture halls, Science Slam, foreign cultural centers (Korean cultural and educational center, Japanese center). It is worthwhile noting that 2 of the 3 lectures are thematic. They are given at the Art Museum and the Young Spectator Theater, the content relating to the activities of these institutions. The educational venue «Persona Grata» offers a wider range of topics, but does not have a permanent location. Japanese and Korean cultural centers are also highly specialized and occupy their own niche in the cultural space of the city. The Science Slam project is held several times a year in a science stand-up format, which is a new one for the city. However, during the time between events it does not satisfy the citizens' cognitive need.

Traditionally, museums and libraries are multifunctional cultural centers that carry out educational, pedagogical and recreational activ- 
ities, organize musical nights, film screenings, and master classes of various types. The largest centers in Khabarovsk are the Khabarovsk Regional Museum named after N. I. Grodekov, the Art Museum, the Far Eastern State Scientific Library, and the Khabarovsk Regional Children's Library named after N. D. Navolochkin.

It is also important to point out that a number of institutions implement the cultural program as an additional, rather than the main one. These are cafes and bars that regularly provide concert venues for the local musicians' performances, organize acoustic and literary parties: the soul cafe «Evenings», the bar «Beer beard», the rock bar «Garage», the cafe «Spicy» and others. It should be particularly emphasized that there are more and more institutions of this kind. Today, newly opened organizations tend to provide various services, which are not limited to a narrow field. These are, for examples, the bookstores «KnizhZHuchki» and «Remarka», which offer master classes for their visitors and also act as discussion book clubs.

What is obvious in the city is the lack of educational projects of a new format. Additional educational services are provided by only $6 \%$ of cultural institutions in Khabarovsk.

The geographical distribution of organizations on the territory of different districts of Khabarovsk is important in the analysis of the network of cultural institutions of the city. So is the identification of the percentage of cultural institutions working in different directions in each district.

Administratively, Khabarovsk is divided into 5 districts: Central District; Krasnoflotskii district; Kirovskii districts; Railway District; Industrial District. The districts differ in the area occupied and the population: Central district ( $9.6 \mathrm{~km}$; 98305 people); Krasnoflotskii district (64.4 km; 91494 people); Kirovskii district (9.2 km; 53417 people); Railway district (94.4 $\mathrm{km}$; 152275 people); Industrial district $(80 \mathrm{~km}$; 222659 people).

There are 9 institutions located in Kirovskii district, which makes about $10 \%$ of the total number. Attention is drawn to the various activities of the organizations in the district. The institutions of Kirovskii district are included in 7 of the 10 categories we have identified: museum organizations, parks, concert venues, art studios, libraries/book clubs, cinemas/film clubs, and zoos. It should be noted that in percentage terms art studios are the most represented: $34 \%$ (3 of the total number of organizations in the district). The institutions of other categories mentioned above are represented by $11 \%$ ( 1 of the total number). This result is achieved due to the fact that the art space «Platonnika» is presented in several categories at once, as it performs the functions of a concert venue and a film club and also provides the services of an art studio.

11 of the 89 registered organizations are located in Railway district of the city, which is $13 \%$ of the total number. The largest number of cinemas/film clubs is in this district: 4 out of 11 (37\% of the total number in the district). Libraries/book clubs in Railway district make up $18 \%$ of the total network of cultural organizations. The share of museum organizations is also $18 \%$. As for art studios, galleries, and zoos, each type of organizations constitutes $9 \%$ of the total. Thus, despite a fairly wide range of organizations, there is a noticeable predominance of only one category, the category being cinemas/film clubs.

In Krasnoflotskii district there are only 4 organizations (5\% of the total number of organizations in the city) working in 4 different areas: museums, parks, concert venues, and cinemas/film clubs. Accordingly, each of the presented categories accounts for $25 \%$ of the total network of institutions in the district. It should be noted that the Amur zoo named after V.S. Sysoev is located not in the territory of the city. Yet, geographically it is closest to the border of Krasnoflotskii district.

In the Industrial district of the city there are 9 institutions (10\% of the total number), representing 6 categories: parks (2 organizations; $22 \%$ ); concert venues ( 2 organizations; $22 \%$ ); libraries/book clubs (2 organizations; $22 \%$ ); museum organizations (1 organization; $11 \%)$; cinemas/film clubs (1 organization; $11 \%$ ); theaters/theater studios (1 organization; $11 \%)$.

It is in Central district of the city - the historical and cultural center of Khabarovsk where most of the cultural organizations are 
concentrated. These are 55 institutions $(62 \%$ of the total number). It is obvious that in this area there is a wide range of the companies of all categories: museum organizations (10 organizations; $21 \%$ of the total number in the area); galleries/exhibition spaces (4 organizations; $8 \%$ of the total); zoos $(1 ; 2 \%$ of the total); theatres/theatre studios ( 9 organizations; $19 \%$ of the total); library/book clubs (4 of the organization; $9 \%$ of the total); parks (4 organizations; $9 \%$ of the total number); art studios (2 organizations; $4 \%$ of the total); cinemas/film clubs ( 7 companies; $15 \%$ of the total number); educational venues ( 6 organizations; $13 \%$ of the total number).

Based on the information obtained during the analysis, a number of conclusions can be drawn. First of all, it is important to point out that cultural organizations in the city are extremely unevenly distributed. Most of the institutions are located in Central District of Khabarovsk, which is the most densely populated, but surpasses only Kirovskii district in its area. At the same time, such large areas as Railway, Industrial and especially Krasnoflotskii districts are extremely poorly provided with cultural institutions. It is interesting to note that the most evenly distributed organizations in the city are from the categories of museum organizations, libraries/book clubs, concert venues, cinemas/film clubs. With rare exceptions, they are found in all areas of the city. It is worthwhile emphasizing the fact that all the educational venues listed above are also grouped in Central District.

Thus, it becomes clear that the cultural space of the city has a number of disadvantages. Firstly, it is the uneven distribution of cultural institutions across the vast territory of Khabarovsk. Secondly, there is an imbalance in the representation of various types of cultural activities both at the city level and the district one. Thirdly, there is a lack of educational projects and educational centers. Fourthly, an important conclusion in the context of this study is that, despite a certain variety of cultural institutions in the city, there are, nevertheless, new formats of organization-art space, which indicates the need for self-expression among the citizens.
Being one of the largest settlements of the region as a whole, Khabarovsk (similar to Komsomolsk-on-Amur) is distinguished by a large variety of categories of cultural institutions and the internal quantitative diversity of the cultural space. These two cities account for more than half of all analyzed cultural institutions: 91 (41\%) are in Khabarovsk, 45 (20\%) are in Komsomolsk-on-Amur.

Komsomolsk-on-Amur is the second largest city in Khabarovsk Territory. It is the administrative center of Komsomolsk Municipal District. The city is located on the left bank of the Amur River, northeast of Khabarovsk. It is an industrial center of the region. The population is 244768 . The work of 45 institutions was under the research $(20 \%$ of the total number of analyzed institutions in the region). The analysis of their work allowed us to identify the same categories as in the cultural space of Khabarovsk:

1) museum organizations (4;8\% of the total number in the city);

2) galleries/exhibition spaces (2; $4 \%$ of the total number);

3) zoos (2; $4 \%$ of the total number);

4) theaters/theater studios $(6 ; 13 \%$ of the total number); total);

5) libraries/book clubs $(10 ; 21 \%$ of the

6) parks $(6 ; 13 \%$ of the total number);

7) concert venues $(6 ; 13 \%$ of the total number); ber);

8) art studios (2s; $4 \%$ of the total num-

9) cinemas/film clubs $(7 ; 15 \%$ of the total number);

10) educational venues $(3 ; 6 \%$ of the total number).

Amursk is the administrative center of the Amur District of the Khabarovsk Territory. It is located north of Khabarovsk. The population is 38913. The study of the cultural environment of the city has revealed 15 institutions ( $7 \%$ of the total number) of culture from 8 categories:

1) museum organizations $(1 ; 6 \%$ of the total number);

2) parks $(3 ; 19 \%$ of the total number);

3) libraries/book clubs $(4 ; 25 \%$ of the total number); 
4) cinemas/film clubs $(1 ; 6 \%$ of the total number);

$5)$ concert venues $(2 ; 13 \%$ of the total number);

$6)$ art studios $(1 ; 6 \%$ of the total number);

7) educational venues $(3 ; 19 \%$ of the total number);

8) theaters/theater studios $(1 ; 6 \%$ of the total number).

Sovetskaya Gavan is a city in Khabarovsk Territory. It is the administrative center of Sovetsko-Gavansky District. It is located in the south of the Khabarovsk Territory. The population is 23550 . The analysis of the network of cultural institutions in the city made it possible to identify 8 institutions ( $4 \%$ of the total number) in the following categories:

1) libraries/book clubs $(1 ; \sim 13 \%$ of the total number);

2) museum organizations $(1 ; \sim 13 \%$ of the total number);

3) educational venues $(2 ; 25 \%$ of the total number);

4) $\operatorname{parks}(1 ; \sim 13 \%$ of the total number);

5) concert venues $(1 ; \sim 13 \%$ of the total number);

6) theaters/theater studios $(1 ; \sim 13 \%$ of the total number);

7) cinemas/film clubs $(1 ; \sim 13 \%$ of the total number).

Nikolayevsk-on-Amur is a city in the Khabarovsk Territory. It is the administrative center of the Nikolayevsky District. It is located north of Khabarovsk, on the Amur River. The population is 17939 .

Cultural institutions of the city (7 institutions; $3 \%$ of the total number) can be divided into 6 categories:

1) museum organizations $(1 ; \sim 14 \%$ of the total number);

2) educational sites $(2 ; 29 \%$ of the total number);

3) concert venues $(1 ; \sim 14 \%$ of the total number);

4) libraries/book clubs $(1 ; \sim 14 \%$ of the total number);

5) cinemas/film clubs $(1 ; \sim 14 \%$ of the total number);

6) $\operatorname{parks}(1 ; \sim 14 \%$ of the total).
Vyazemsky is a city in Khabarovsk Territory. It is the administrative center of Vyazemsky District. It is located in the south of the Khabarovsk Territory. The population is 12999. The network of cultural institutions consists of 7 institutions ( $3 \%$ of the total number) and is divided into 6 groups:

1) museum organizations $(1 ; \sim 14 \%$ of the total number);

2) libraries/book clubs $(2 ; 29 \%$ of the total);

3) cinemas/film clubs $(1 ; \sim 14 \%$ of the total number);

4) concert venues $(1 ; \sim 14 \%$ of the total number);

5) educational venues $(1 ; \sim 14 \%$ of the total number);

6) parks.

Bikin is a city in Khabarovsk Territory. It is the administrative center of the Bikinsky District. It is located in the south of the region, on the bank of the Bikin River. The population is 16104 . The study of the network of cultural institutions in Bikin (5 institutions, $2 \%$ of the total number) reveals the work of 5 categories of institutions:

1) museum organizations $(1 ; 14 \%$ of the total number);

2) concert venues $(2 ; 29 \%$ of the total number);

3) libraries/book clubs $(2 ; 29 \%$ of the total number);

4) cinemas/film clubs $(1 ; 14 \%$ of the total number);

5) parks (1; $14 \%$ of the total).

Vanino is a work settlement in the south of the Khabarovsk Territory It is the administrative center of the Vaninsky District. The population is 15167 .

The network of cultural institutions of Vanino, studied in the course of the researcg, has 8 institutions ( $4 \%$ of the total number) in 5 categories:

1) museum organizations $(2 ; 22 \%$ of the total number);

2) libraries/book clubs $(3 ; 33 \%$ of the total number);

3) cinemas/film clubs $(1 ; 11 \%$ of the total number);

4) educational sites $(2 ; 22 \%$ of the total number); 
5) parks $(1 ; 11 \%$ of the total).

Troitskoye is a village in the Khabarovsk Territory. It is the administrative center of the Nanaisky District. It is located in the south of the Khabarovsk Territory. The population is 4677.

The analysis of the network of cultural institutions consisting of 6 institutions ( $3 \%$ of the total number) allowed us to distinguish the following categories:

1) libraries/book clubs $(1 ; \sim 17 \%$ of the total number);

2) museum organizations $(1 ; \sim 17 \%$ of the total number);

$3)$ educational venues $(2 ; \sim 33 \%$ of the total number);

4) theaters/theater studios $(1 ; \sim 17 \%$ of the total number);

5) concert venues $(1 ; \sim 17 \%$ of the total).

Okhotsk is a work settlement in the Khabarovsk Territory/ It is the administrative center of the Okhotsky District. It is located in the north of the Khabarovsk Territory. The population is 3183 .

In the network of cultural institutions of the village ( 4 institutions, $2 \%$ ) there can be distinguished 4 categories:

1) museum organizations $(1 ; 25 \%$ of the total number);

2) libraries/book clubs $(1 ; 25 \%$ of the total number);

3) concert venues $(1 ; 25 \%$ of the total number);

4) educational venues $(1 ; 25 \%$ of the total number).

Pereyaslavka is a work settlement in the Khabarovsk Territory. It is the administrative center of the Imeni Lazo District. It is located in the south of the Khabarovsk Territory. The population is 7469 .

The network of cultural institutions of the village, consisting of 5 institutional organizations ( $2 \%$ of the total number), includes 5 categories:

1) libraries/book clubs $(2 ; 33 \%$ of the total number);

2) museum organizations $(1 ; \sim 17 \%$ of the total number);

3) concert venues $(1 ; \sim 17 \%$ of the total number);
4) theaters/theater studios $(1 ; \sim 17 \%$ of the total number);

5) educational venues $(1 ; \sim 17 \%$ of the total number).

Solnechny is a work settlement in the Khabarovsk Territory. It is the administrative center of the Solnechny District. It is located in the center of the Khabarovsk Territory. The population is 11601 .

The categories of 5 cultural institutions are represented in the village (2\% of the total number):

1) libraries/book clubs (2; $40 \%$ of the total number);

2) cinemas/film clubs $(1 ; 20 \%$ of the total number);

3) museum organizations $(1 ; 20 \%$ of the total number);

4) concert venues $(1 ; 20 \%$ of the total number).

Chegdomyn is a work settlement in the Khabarovsk Territory. It is the administrative center of the Verkhnebureinsky District. It is located in the central part of the Khabarovsk Territory. The population is 11652 .

The research of the network of cultural institutions of the village has revealed the following categories of 5 institutions ( $2 \%$ of the total number):

1) museum organizations $(1 ; 20 \%$ of the total number);

2) libraries/book clubs $(2 ; 40 \%$ of the total number);

3) cinemas/film clubs $(1 ; 20 \%$ of the total number);

4) concert venues $(1 ; 20 \%$ of the total number).

Ayan is a village in the Khabarovsk Territory. It is the administrative center of the Ayano-Maysky District. It is located in the north of the Khabarovsk Territory. The population is 817 .

The village has 2 cultural institutions ( $1 \%$ of the total) from the categories:

1) libraries/book clubs $(1 ; 50 \%$ of the total number);

2) concert venues $(1 ; 20 \%$ of the total number).

Bogorodskoye is a village in the Khabarovsk Territory. It is the administrative 
center of the Ulchsky District. The population is 3272 .

The network of cultural institutions of the village is limited to 3 institutions ( $1 \%$ of the total number), forming 3 categories:

1) libraries/book clubs $(1 ; \sim 33 \%$ of the total number);

2) museum organizations $(1 ; \sim 33 \%$ of the total number);

$3)$ concert venues $(1 ; \sim 33 \%$ of the total).

Imeni Poliny Osipenko is a village in the Khabarovsk Territory. It is the administrative center of the Imeni Poliny Osipenko District. It is located in the south of the Khabarovsk Territory. The population is 1949 .

Its cultural institutions can be divided into 2 categories, including 3 institutions (1\% of the total number): total);

1) libraries/book clubs $(2 ; \sim 67 \%$ of the

2) museum organizations $(1 ; \sim 33 \%$ of the total number).

Chumikan is a village in the Khabarovsk Territory. It is the administrative center of the Tuguro-Chumikansky District. It is located in the northern part of the Khabarovsk Territory. The population is 1091 .

The village has 2 cultural institutions (1\% of the total), representing 2 categories:

1) libraries/book clubs $(1 ; 50 \%$ of the total number);

2) concert venues $(1 ; 50 \%$ of the total number).

Thus, our study of the networks of cultural institutions of the administrative centers in the Khabarovsk Territory districts allows us to draw a number of conclusions about the nature of the cultural space of the entire region. Attention is drawn to the different degree of prevalence of institutions of different categories in the region. Thus, the only category represented in all the listed localities is the library group. It is also the most numerous and includes 45 names, which is $20 \%$ of the total number of cultural institutions. The categories of museum organizations, cinemas/film clubs and concert venues are also quite widespread and are found in most localities, including 32 (14\%), 29 $(13 \%)$ and $35(15 \%)$ institutions, respectively. The remaining categories are less common and each makes up no more than $10 \%$ of the total. The least represented are zoos and galleries/exhibition spaces. They are found only in the two largest cities of the region (Khabarovsk and Komsomolsk-on-Amur) and include 6 (2\%) and $7(3 \%)$ institutions, respectively.

In general, the cultural space of the region is characterized by the predominance of state cultural institutions. Although private institutions are emerging, they are developing slowly and mainly in large localities.

The study of the network of cultural institutions in the region allows us to form an idea of the prevalence of certain types of cultural institutions and forms of their interaction with the residents. The data collected during the preparatory stage of the cultural expertise also allow us to identify institutions for the further research. The method of cultural expertise will allow us to make a conclusion about the degree of their belonging to the format of art space.

\section{References}

Nikiforova, L.V., Ron, M.V., Tikhomirov, S.A., Makashova, A.S., Poddelkova, P.E. (2011). Prostranstvo universitetskoi povsednevnosti: prikladnoe issledovanie $\mathrm{v}$ formate kul'turologicheskoi ekspertizy [The space of university everyday life: applied research in the format of cultural expertise]. In Universum: Vestnik Gertsenovskogo universiteta [Universum: Herzen University Bulletin], 7, 60-70.

Sadokhin, A.P. (2012). Teoretiko-metodologicheskie resursy kul'turologicheskoi ekspertizy [Theoretical and methodological resources of cultural expertise]. In Kul'turologicheskii zhurnal [Journal of Cultural Studies], 3(9). Available at: http://cr-journal.ru/rus/journals/148.html\&j_id=11 